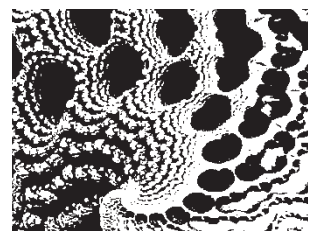

\title{
COPING STRATEGIES IN WAR VETERANS 20 YEARS AFTER THE EXPOSURE TO EXTREME STRESS
}

Martina KNEŽEVIĆ

Centre for Croatian Studies, Zagreb

Dino KRUPIĆ

Faculty of Humanities and Social Sciences, Osijek

Sandra ŠUĆUROVIĆ

Assembly of Associations of Croatian Guard Units Veterans, Zagreb

UDK: 159.944.4-057.36-057.75(497.5) 616.891-057.36-057.75(497.5)

Izvorni znanstveni rad

Primljeno: 9. 3. 2016.

Acknowledgements This research was supported by a grant from the Ministry of Veterans' Affairs of the Republic of Croatia. We sincerely thank the veterans who participated in this study.
Many soldiers encounter difficulties while transitioning from military to civilian life. Such severe traumatic events may also have long-term effects. Previous studies have shown a strong relationship between coping strategies and posttraumatic stress disorder (PTSD) symptoms. The aim of this study was to investigate how veterans who were exposed to war trauma 20 years ago now deal with everyday life stressors, and how their current coping strategies relate to the four-factor model of PTSD. A total of 220 male Croatian Homeland War Veterans between the ages of 38 and 75 participated. Questionnaires included Combat Exposure Scale, Posttraumatic Stress Disorder Checklist - Military Version and Ways of Coping Questionnaire. Results showed positive association between dysphoria and escape-avoidance coping strategy and negative association between dysphoria and positive reappraisal coping strategy. Given that dysphoria symptoms are associated with the chronicity of PTSD and poorer response to PTSD therapy treatment in war veterans, our results underscore the importance of treating dysphoria symptoms and promoting engagement coping strategies for this population.

Keywords: stress, four-factor PTSD model, coping strategies, war veterans, therapy planning

Martina Knežević, Department of Psychology, Centre for Croatian Studies, University of Zagreb, Borongajska cesta 83d, 10000 Zagreb, Croatia. E-mail: mknezevic@hrstud.hr 
Devastating consequences of war horrors on active soldiers are very well-known and they do not end with the conclusion of the armed conflict. Upon returning from the combat zone, many soldiers encounter difficulties while readjusting to life with family, friends, and community and may experience a variety of common stress reactions (Hoge, Riviere, Wilk, Herrell, \& Weathers, 2014; Zerach, Solomon, Cohen, \& Ein-Dor, 2013). For most of the soldiers, these reactions gradually weaken with time. However, they can consolidate into a chronic disorder known as posttraumatic stress disorder (PTSD) (Peterson, Luethcke, Borah, Borah, \& Young-McCaughan, 2011). The original diagnostic criteria for PTSD included 12 symptoms grouped into three clusters: re-experiencing, numbing, and a heterogeneous cluster of guilt, avoidance, nonspecific memory impairment and autonomic hyperarousal. After extensive revisions of the underlying symptoms, currently the most supported PTSD model is the four-factor model distinguishing; (a) re-experiencing, i.e. intrusive thoughts and flashbacks, (b) avoidance, i.e. of thoughts or trauma reminders, (c) dysphoria, i.e. loss of interest and restricted range of affect; and (d) hyperarousal, i.e. hypervigilance and exaggerated startle response (Armour, 2015; Bensimon et al., 2013; Palmieri, Weathers, Difede, \& King, 2007).

Coping strategies are defined as an individual's voluntary efforts to manage specific stressful events. According to Transactional model of stress and coping (Lazarus \& Folkman, 1984), if an event exceeds a person's coping capacity, it will be perceived as stressful, especially if his/her wellbeing is recognized as being at stake. People generally use a variety of coping strategies, which are often divided into engagement and disengagement coping (Lazarus \& Folkman, 1984). Choice and effectiveness of the coping strategy is determined by the particular characteristics of a stressful situation. Previous studies have shown a strong relationship between coping strategies and PTSD symptoms. Benotsch et al. (2000) examined 348 Gulf War veterans at two different time intervals after returning from the war zone, measuring PTSD symptoms, dispositional resilience, coping strategies, personal resources, and social support. At the first time interval 14 months after the trauma, those with more severe PTSD symptoms were characterized by avoidance coping and lack of family cohesion. The second time interval was about 2 years after, and showed that the avoidance coping and a general decrease in perceived social support resources predicted the level of PTSD symptoms. Sharkansky et al. (2000) examined 2,949 Gulf War veterans measuring combat exposure, coping styles, PTSD 
DRUŠ. ISTRAŽ. ZAGREB GOD. 25 (2016), BR. 3 STR. 353-370

KNEŽEVIĆ, M., KRUPIĆ, D., ŚUCUROVIĆ, S COPING STRATEGIES.. symptoms and life stressors. They showed that veterans who used active coping styles had fewer PTSD symptoms than veterans who used avoidant coping styles two years after the war. Regardless of coping styles, those with the highest levels of combat exposure had more PTSD symptoms.

PTSD is a persistent phenomenon with lifelong negative consequences, and coping strategies can affect the onset, maintenance and the level of PTSD symptoms (Abouzeid, Kelsall, Forbes, Sim, \& Creamer, 2012; Amir et al., 1997; Bae, Hyun, \& Ra, 2015; Benotsch et al., 2000; Bensimon, 2012; Brousse et al., 2011; Morris \& Rao, 2013). Most of the studies that investigated coping strategies used by trauma victims were conducted in the immediate aftermath of the trauma. However, severe traumatic events like war trauma may also have long-term effects: occupational and social functional impairment, health problems, high comorbidity with other psychiatric disorders, and reduced quality of life even several decades after the war (Aldwin, Levenson, \& Spiro, 1994; Hoge \& Warner, 2014; Sareen et al., 2007; Wisco et al., 2014). In rare studies examining the long-term consequences of war-related PTSD symptoms, Zeiss and Dickman (1989) found that 56\% of former prisoners during World War II have reported that they still experience PTSD symptoms even 40 years after the trauma, while Aldwin et al. (1994) found lifelong negative consequences of combat exposure in early adulthood on PTSD symptoms nearly 50 years after the trauma. These studies evidenced that combat-related PTSD is a highly persistent phenomenon, and may have a significant impact on one's wellbeing several decades after experiencing the traumatic event.

According to Ehlers and Clark's cognitive model of PTSD (Ehlers \& Clark, 2000), it is not the traumatic event itself that influences PTSD levels, but one's coping with the event and its consequences. If an individual appraises his/her reactions to traumatic event as a threat to physical or mental well-being, their appraisal can encourage them to engage in dysfunctional coping strategies that consequently enhance their PTSD symptoms (Brewin \& Holmes, 2003; Ehlers \& Clark, 2000). Research shows that individuals who engage in maladaptive coping strategies while exposed to stressors diminish their available resources and consequently increase the stress levels. In turn, increased stress levels are associated with greater reliance on maladaptive coping strategies (Benotsch et al., 2000; Morris \& Rao, 2013; Solomon, Mikulincer, \& Flum, 1988). In line with this, we expected to find negative correlations between active problem-focused coping strategies and the level of PTSD symptoms, and positive correlations between maladaptive, avoidant coping strategies and the level of PTSD 
DRUŠ. ISTRAŽ. ZAGREB GOD. 25 (2016), BR. 3, STR. 353-370

KNEŽEVIĆ, M., KRUPIĆ D., ŠUĆUROVIĆ, S.: COPING STRATEGIES..

\section{METHOD}

\section{Participants}

\section{Measures}

symptoms in war veterans. Since the levels of exposure to traumatic war events are associated with greater symptoms, we also assessed combat exposure, as well as other variables that could influence the level of PTSD symptoms, i.e. age, social status, and therapy treatment. Our goal was to control these variables in order to detect a relationship between coping strategies and PTSD subscales (re-experiencing, avoidance, dysphoria, hyperarousal).

A total of 220 male Croatian Homeland War Veterans were included in this study, ranging from 38 to 75 years of age ( $M=$ $50.6 ; S D=6.9$ ). Most of the participants have completed high school $(83 \%)$ or college $(11.5 \%)$, while $5.5 \%$ completed primary education. Regarding their marital status, $79.7 \%$ are married, $10.2 \%$ divorced, $7.8 \%$ single and $2.3 \%$ widowed. The majority are now retired military veterans $(78.3 \%)$, and the rest are employed $(11.1 \%)$, unemployed $(5.5 \%)$ or civilian retirees $(5.1 \%)$. They joined their troops as Homeland War volunteers $(93.2 \%)$ or were recruited $(6.8 \%)$. On average, they spent 45 months in the Homeland War $(M=45.3$; $S D=18.3)$, of which 36 months on the frontline $(M=36.3$; $S D=20.4)$. There were $3.6 \%$ participants who were exposed to light combat, $10.9 \%$ to light-moderate, $25 \%$ to moderate, $36.8 \%$ to moderate heavy, and $23.7 \%$ to heavy combat exposure. Among the participants $61.8 \%$ scored 50 or more on the Posttraumatic stress disorder checklist - military version, which is assumed to be the cut-point in military research, and everyone who meets this threshold also meets DSM-IV criteria (Wilkins, Lang, \& Norman, 2011; Wisco et al., 2014). Before the Homeland War, the majority of the participants $(94.1 \%)$ never received psychiatric help, but after the war, more than half $(51.8 \%)$ received some form of psychiatric care, while one third $(36 \%)$ is currently in treatment.

For the purposes of this study, we constructed a socio-demographic data questionnaire, which included information on age, residence, education, employment, marital status and children, monthly incomes and financial status, psychiatric and medication treatment before/after the war, and military service (entrance, duration, function and termination).

The original English versions of PCL-M and CES were first independently forward-translated by a group of 4 psychologists, fluent in Croatian and English. After comparing 
DRUŠ. ISTRAŽ. ZAGREB GOD. 25 (2016), BR. 3 STR. 353-370

KNEŽEVIĆ, M., KRUPIĆ, D., SUCUROVIC, S. COPING STRATEGIES.. the results and agreeing on final versions by two authors of this study, PCL-M and CES were back-translated by an English professor and compared to the original versions.

Combat exposure scale (CES) (Keane et al., 1989) was used to assess wartime stressors experienced by combatants. This is a 7-item self-report measure, with a 5-point frequency scale. Scores are weighted and summed to a total score between 0 and 41, which can be classified into one of five categories ranging from light combat to heavy combat. CES is often used in both research and clinical settings (Carvalho, Pinto-Gouveia, Cunha, \& da Motta, 2014; Keane et al., 1989). Confirmatory factor analysis (CFA) conducted on our data revealed adequate model fit indices for the unidimensional CES. Goodness of fit were Sattora-Bentler scaled $\chi^{2}=32.11$, $d f$ $=14, p<0.01, C F I=0.985$, and RMSEA $=0.080$.

To measure DSM-IV symptoms of PTSD, we used the Posttraumatic stress disorder checklist - military version (PCL-M) (Blanchard, Jones-Alexander, Buckley, \& Forneris, 1996; Hoge \& Warner, 2014). PCL-M is a 17-item self-report scale assessing the level of symptoms in response to "stressful military experiences". A total symptom severity score (range $=17-85$ ) can be obtained by summing the scores from each item that have response options ranging from 1 "Not at all" to 5 "Extremely". The $\geq 50$ cut-point is a standard for military research (Bliese et al., 2008; Forbes, Creamer, \& Biddle, 2001). However, CFA indicated poor model fit of the unidimensional model of PCL-M $\left(\chi^{2}=757.16, d f=119, p<0.01, C F I=0.973\right.$, and $R M S E A=0.159)$. We examined the four-factor oblique model proposed by Palmieri et al. (2007), consisting of re-experiencing, avoidance, dysphoria and hyperarousal subscales. CFA resulted in adequate model fit, $\chi^{2}=218.03, d f=113, p<0.01$, $C F I=0.996$, and RMSEA $=0.066$.

Ways of coping questionnaire (WOC) was administered as a measure of thoughts and actions used to handle stressful situations (Folkman \& Lazarus, 2011). It consists of 66 questions, and individuals respond on a four-point Likert scale indicating the frequency with which each strategy is used. WOC measures eight coping strategies: (1) confrontive coping - aggressive efforts to alter the situations, suggesting some degree of hostility and risk-taking; (2) distancing - cognitive efforts to detach oneself and minimize the significance of the situation; (3) self-controlling - efforts to regulate one's feelings and actions; (4) seeking social support - efforts to seek informational, tangible, and emotional support; (5) accepting responsibility - acknowledges one's own role in the problem and trying to put things right; (6) escape-avoidance - wishful thinking and behavioral efforts to escape or avoid the prob- 
DRUŠ. ISTRAŽ. ZAGREB GOD. 25 (2016), BR. 3, STR. 353-370

KNEŽEVIĆ, M., KRUPIĆ, D., ŠUĆUROVIĆ, S.: COPING STRATEGIES..

\section{Procedure}

\section{Ethical considerations}

Data collection and privacy protection were in accordance with ethical principles, Croatian laws and international laws on the ethics of scientific research (1964 Declaration of Helsinki, APA). The participants were informed about the purpose of the study, assured that their participation in the study was completely voluntary and that they have the right to quit their participation at any stage if they did not feel comfortable continuing the process. Prior to taking part in the study, each gave written informed consent. The confidentiality of the data was ensured by identification numbers.

\section{Analytic plan}

lem; (7) planful problem solving - deliberate problem-focused efforts to alter the situation and analytic approach to solving the problem; (8) positive reappraisal - efforts to create posireligious dimension. Participants were instructed to answer the questions about coping strategies in relation to stressors that they encounter in their everyday living.

This study was a part of a project conducted in collaboration the Ministry of Veterans Affairs of the Republic of Crowere corticipants were recruited on a voluntary basis. They aim and the procedure of the research, and asked to participate in the study. The inclusion criterion was Croatian Homeland War Veteran status. According to the Croatian Constitution, Croatian Homeland War Veterans are persons who joined and actively participated in the armed defense of Croatia during the Homeland War that lasted from 1990 to 1996. Their Upon arrival at the war veteran association offices, where the research was conducted, each participant received an Information letter with a detailed description of the research, and a trained psychologist explained the procedure orally. Each gave written informed consent prior to taking part in the battery included a socio-demographic questionnaire, Combat exposure scale, Posttraumatic stress disorder checklist - military version, and Ways of coping questionnaire. The completion of all questionnaires lasted between 45 and 60 minutes.
For the purpose of this study, we translated CES into the Croatian language. Since it had not yet been validated, we examined its factor structure by means of CFA. Also, since 
DRUŠ. ISTRAŽ. ZAGREB GOD. 25 (2016), BR. 3 STR. 353-370

KNEŽEVIĆ, M., KRUPIĆ, D., SUUCUROVIĆ, S. COPING STRATEGIES.. there were several alternative models proposed for PCL (Palmieri et al., 2007), we also conducted CFA for PCL-M. As model fit indices, the Sattora-Bentler scaled chi-square $\left(\chi^{2}\right)$ (Bentler, 2006; Satorra \& Bentler, 2001) showed closeness of fit between the unrestricted sample correlation matrix and the restricted (model) correlation matrix. In addition, we took into account the root mean squared error of approximation (RMSEA; Steiger, 2000), the comparative fit index (CFI; Bentler, 1990). RMSEA values of $<0.05$ were taken as a good fit, $0.05-0.08$ as a moderate fit, $0.08-0.10$ as a marginal fit and $>0.10$ as a poor fit (Hu \& Bentler, 1999), while the CFI values between 0.90 and 0.95 indicated acceptable fit, and values above 0.95 indicated good fit (Hu \& Bentler, 1999). CFA was conducted by EQS 6.1. using polychoric correlation matrices with Maximum Likelihood Estimation method. The reason for using polychoric correlation is in the response format of PCL-M which includes less than a 6-point rating scale, and the response format of CES, which do not have equidistant units of response format.

The relationship between PCL-M and WOC was analyzed by set correlation analysis (SCA), which provides statistical control for the set of research factors (in our case age, socioeconomic status, months spent on the first line, medical and psychosocial treatment, combat exposure), when relating one set of variables (in our case PCL-M) to another (in our case WOC). Furthermore, it controls covariance within both sets of variables. In this way, confounding effects of other variables were held under control, and the likelihood of Type I error was reduced, promoting the uniqueness of the relationship between two variables (Cohen, Cohen, West, \& Aiken, 2003). In other words, coefficients in the matrix in our case represent partial correlation coefficients. This procedure is very useful in designs where several inter-correlated predictors are tested in prediction of several inter-correlated criterion variables.

\section{RESULTS}

Cronbach alpha reliability coefficients for all variables are presented in Table 1 . The reliability coefficients for the coping strategies (WOC) subscales - confrontive coping, distancing, self-control, seeking social support, accepting responsibility, escape-avoidance, planful problem solving and positive reappraisal - are below 0.70 , possibly due to a relatively small number of items per scale. However, an additional measure of internal consistency, the average intercorrelation, in range of 0.21 to 0.26 , shows that the scales have adequate psychometric characteristics (Clark \& Watson, 1995; Netemeyer, Bearden, \& Sharma, 2003). 


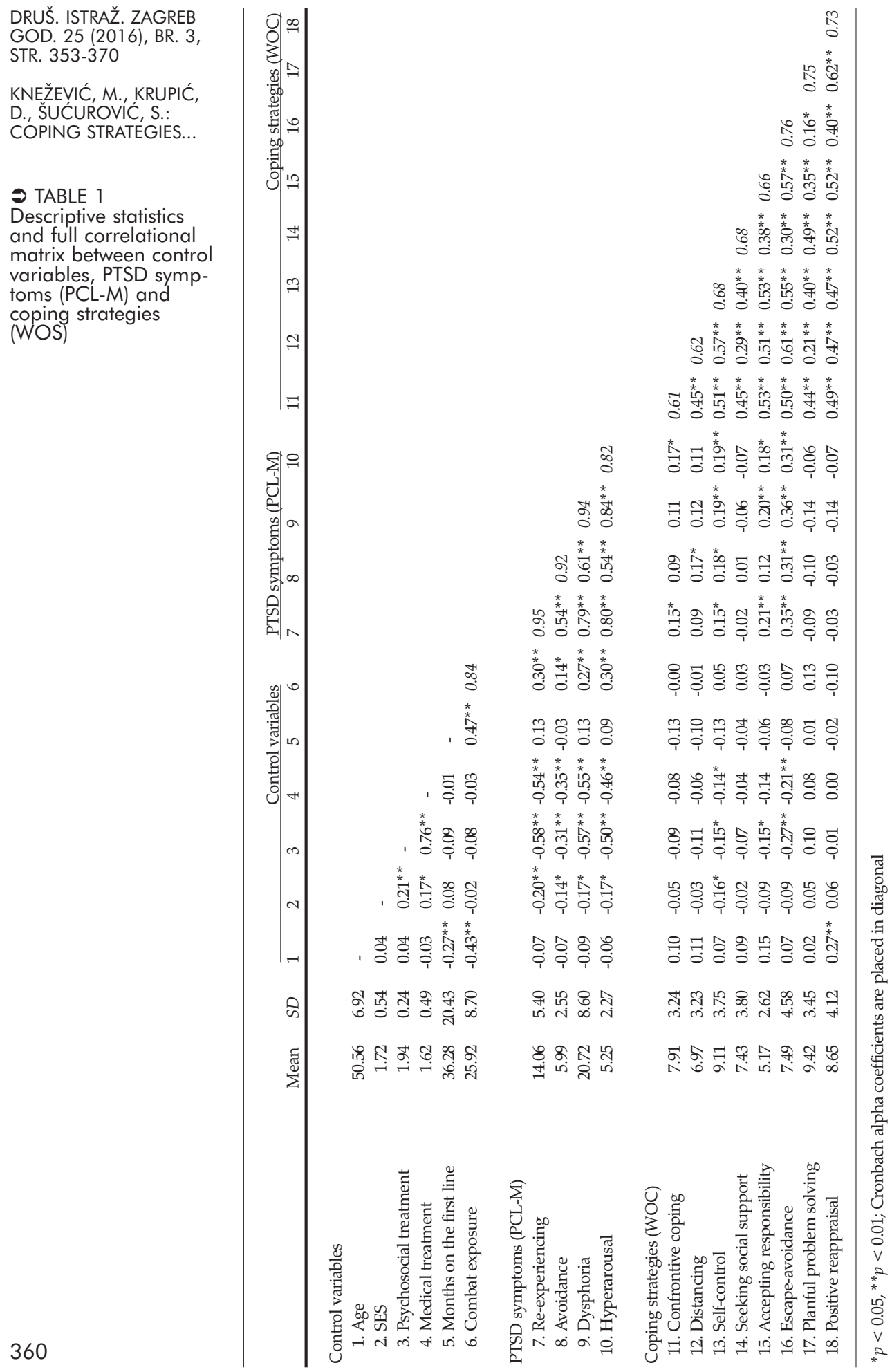




\begin{tabular}{|c|c|c|c|c|c|c|c|c|}
\hline \multicolumn{9}{|c|}{ Coping strategies (WOC) } \\
\hline & $\begin{array}{r}\text { Confrontive } \\
\text { coping }\end{array}$ & Distancing & $\begin{array}{r}\text { Self- } \\
\text {-control }\end{array}$ & $\begin{array}{r}\text { Seeking } \\
\text { social } \\
\text { support }\end{array}$ & $\begin{array}{r}\text { Accepting } \\
\text { respon- } \\
\text { sibility }\end{array}$ & $\begin{array}{r}\text { Escape- } \\
\text {-avoidance }\end{array}$ & $\begin{array}{l}\text { Planful } \\
\text { problem } \\
\text { solving }\end{array}$ & $\begin{array}{r}\text { Positive } \\
\text { reappraisal }\end{array}$ \\
\hline \multicolumn{9}{|l|}{ Control variables } \\
\hline Age & 0.10 & 0.12 & 0.09 & 0.13 & $0.15^{*}$ & 0.11 & 0.07 & $0.26^{* *}$ \\
\hline SES & 0.00 & 0.01 & -0.11 & -0.01 & -0.04 & 0.00 & 0.02 & 0.05 \\
\hline Psychosocial treatment & -0.06 & $-0.17^{*}$ & -0.08 & $-0.18^{*}$ & -0.05 & $-0.16^{*}$ & 0.04 & -0.09 \\
\hline Medical treatment & 0.04 & 0.13 & 0.01 & 0.00 & 0.04 & 0.12 & -0.06 & -0.01 \\
\hline Months on the first line & $-0.15^{*}$ & -0.10 & $-0.16^{*}$ & -0.06 & -0.05 & -0.13 & -0.04 & 0.06 \\
\hline CES & 0.05 & 0.06 & 0.12 & $0.15^{*}$ & -0.01 & 0.07 & $0.21^{*}$ & 0.02 \\
\hline \multicolumn{9}{|l|}{ PTSD symptoms (PCL-M) } \\
\hline Re-experiencing & 0.11 & -0.09 & -0.12 & 0.02 & 0.17 & 0.13 & -0.07 & 0.13 \\
\hline Avoidance & 0.00 & 0.15 & 0.08 & 0.08 & -0.01 & 0.12 & -0.02 & 0.08 \\
\hline Dysphoria & -0.11 & 0.08 & 0.10 & -0.14 & 0.13 & $0.20^{*}$ & $-0.24^{* *}$ & $-0.36^{* *}$ \\
\hline Hyperarousal & $0.17^{*}$ & 0.01 & 0.09 & -0.13 & -0.06 & -0.06 & 0.15 & 0.05 \\
\hline$R$ & 0.26 & 0.25 & 0.30 & 0.21 & 0.28 & 0.42 & 0.25 & 0.33 \\
\hline$R^{2}$ & 0.065 & 0.061 & 0.092 & 0.046 & 0.080 & 0.173 & 0.060 & 0.106 \\
\hline$F(10,209)$ & 1.46 & 1.37 & $2.11^{*}$ & 1.01 & 1.81 & $4.36^{* *}$ & 1.34 & $2.48^{* *}$ \\
\hline
\end{tabular}

${ }^{*} p<0.05 ;{ }^{* *} p<0.01$

(1) TABLE 2

Set correlation analysis examining relationships between PTSD symptoms and coping strategies by controlling the effects of age, SES, psychosocial and medical treatment, months on the first line and combat exposure
Table 1 also contains zero order correlations between control variables (age, SES, psychosocial and medical treatment, months on the first line and combat exposure), PTSD symptoms measured by PCL-M (re-experiencing, avoidance, dysphoria, hyperarousal), and coping strategies measured by WOC (confrontive coping, distancing, self-control, seeking social support, accepting responsibility, escape-avoidance, planful problem solving, positive reappraisal). As it can be seen in Table 1, coping strategies that were most related to PTSD symptoms are escape-avoidance, accepting responsibility, and self-controlling. Confrontive coping correlated only with re-experiencing and hyperarousal PTSD symptoms, while distancing correlated with the avoidance PTSD symptom. The rest of the WOC scales did not correlate with PCL-M subscales.

Due to a strong intercorrelation among and between WOC subscales and PCL-M subscales, we conducted SCA that can control the Type I error. Also, as it can be seen in Table 1, control variables (age, SES, psychosocial and medical treatment, months on the first line and combat exposure) show significant effects on both PTSD symptoms and coping strategies. Thus, since the aim was to examine the relationship between coping strategies and PTSD symptoms, we conducted the analysis using SCA in order to control the effects of age, psychosocial and medical treatment, socioeconomic status, time spent on the first line, and combat exposure on PTSD symptoms and coping strategies. Analyzed in this way, our data show the relationship between PTSD symptoms and coping strategies in a more detailed manner, without the confounds that can be caused by the controlled variables. 
DRUŠ. ISTRAŽ. ZAGREB GOD. 25 (2016), BR. 3, STR. 353-370

KNEŽEVIĆ, M., KRUPIĆ D., ŠUĆUROVIĆ, S.: COPING STRATEGIES..

\section{DISCUSSION}

Using the SCA, all canonical variates in the data set were taken into account in one index to provide an overall index of association. The overall relationship between PTSD symptoms and control variables with coping strategies was Cohen's Set Correlation $R^{2}=0.52$, which was statistically significant $F(1.87,80)=1226.31, p<0.01$. Moderate to strong relationships ( $R=0.26-0.42$ ) between PTSD symptoms (controlling for the effects of age, psychosocial and medical treatment, socioeconomic status, time spent on the first line, and combat exposure) and coping strategies were found. Data in Table 2 show partial correlations, i.e. unique relations between PTSD symptoms and coping strategies: positive correlation between dysphoria and escape-avoidance, and negative between dysphoria and positive reappraisal. The rest of the PTSD symptoms (re-experiencing, avoidance, hyperarousal) were not significantly related to coping strategies.

This study examined the associations between coping strategies and combat-related PTSD symptoms on a sample of Croatian male war veterans. Our goal was to investigate how veterans who were exposed to war trauma 20 years ago now deal with everyday life stressors. We explored the relationship between their current coping strategies and the level of combat-related PTSD symptoms, while controlling for variables that show significant effects on PTSD symptoms and coping strategies (age, socioeconomic status, months spent on the first line, medical and psychosocial treatment, combat exposure). Our main findings show positive correlation between dysphoria and escape-avoidance, and negative correlation between dysphoria and positive reappraisal.

As one of the four factors of PTSD symptom clusters, dysphoria reflects the inability to recall aspects of trauma, loss of interest, detachment and restricted affect, sense of foreshortened future, sleep disturbances, irritability, and difficulty concentrating (Palmieri et al., 2007). These symptoms have been liked to a variety of distress factors like anxiety, anger and general psychological distress in various trauma victims (Armour, 2015; Claycomb, Wang, Sharp, Ractliffe, \& Elhai, 2015; Kaysen et al., 2007; Marshall, Schell, \& Miles, 2010). Pietrzak, Goldstein, Malley, Rivers, and Southwick (2010) investigated 272 veterans of operations Enduring Freedom and Iraqi Freedom two years after their deployment and found that dysphoria symptoms were related to a broad range of psychosocial measures. They found positive correlation between dysphoria symptoms and alcohol use problems, psychosocial and family difficulties, work and financial difficul- 
DRUŠ. ISTRAŽ. ZAGREB GOD. 25 (2016), BR. 3 STR. $353-370$

KNEŽEVIĆ, M., KRUPIĆ, D., SUCUROVIC, S. COPING STRATEGIES.. ties, suicidal ideation, and negative correlation with psychological resilience, hardiness, purpose, leadership, unit and post-deployment social support.

Coping is a process used to adjust or reshape negative aspects of the environment and consequently minimize internal threat induced by stress (Amir et al., 1997; Folkman, 1984; Lazarus, 1993). Escape-avoidance coping strategy includes wishful thinking and behavioural effort to escape or avoid the problem. Our results are in line with previous findings, confirming that focusing on personal growth and making efforts to resolve problems are at opposite ends of distress. More specifically, coping strategies that emphasize active problem solving are found to be associated with less severe PTSD symptoms (Agaibi \& Wilson, 2005; Amir et al., 1997; Brousse et al., 2011), while a large body of research has found that avoidance coping behaviours contribute to the severity and chronicity of PTSD (Benotsch et al., 2000; Bensimon et al., 2013; Johnsen, Eid, Laberg, \& Thayer, 2002; Pietrzak, Harpaz-Rotem, \& Southwick, 2011; Tiet et al., 2006). Cognitive theories of PTSD and related therapeutic interventions show that repeated avoidance of intrusive thoughts or emotions may avert habituation to trauma-related cues and consequently their elimination, and delay modification of threat-based beliefs (Brewin \& Holmes, 2003; Ehlers \& Clark, 2000; Pietrzak et al., 2011). According to Ehlers and Clark (2000), if an individual tries hard not to think about the trauma or even uses behavioural efforts to control PTSD symptoms, this will only increase the frequency and persistence of these and other symptoms.

It seems that if veterans use escape-avoidance coping strategy and invest efforts to avoid reminders of the traumatic event in their everyday life, this will actually exacerbate their symptoms, cause prolongation of the suffering and hinder the possibility of the recovery even 20 years after the initial war trauma. Given that dysphoria symptoms are associated with the chronicity of PTSD (Pietrzak et al., 2010) and poorer response to PTSD therapy treatment in war veterans (Hassija, Jakupcak, \& Gray, 2012), our results underscore the importance of treating dysphoria symptoms for this population. Interventions that teach and encourage engagement coping strategies, especially positive reappraisal, may help in reducing combat-related dysphoria symptoms in war veterans. It is also possible that reducing dysphoria symptoms may help decrease maladaptive disengagement coping strategies and promote engagement in more adaptive, problem focused, coping strategies. For example, Cognitive processing therapy and Prolonged exposure therapy have so far been outlined as most effective in reducing PTSD symptoms in war veterans 
DRUŠ. ISTRAŽ. ZAGREB GOD. 25 (2016), BR. 3, STR. 353-370

KNEŽEVIĆ, M., KRUPIĆ D., ŠUĆUROVIĆ, S.: COPING STRATEGIES..
(Foa, 2011; Monson et al., 2006; Mott et al., 2014; Resick, Monson, \& Chard, 2014). Prolonged exposure therapy teaches relaxation and coping techniques, guiding individuals through combat-related stressful thoughts and memories while they use coping strategies or discuss memories of the event. The focus is on changing maladaptive behaviours which in turn change negative cognitive constructs (Foa, 2011). Cognitive processing therapy consists of several phases, including education on PTSD, thoughts and emotions, and learning to challenge unhelpful trauma-related thoughts through cognitive interventions (Resick et al., 2014).

Limitations of this study include using only the self-reporting method in measuring the level of PTSD symptoms, and cross-sectional design, which prevented us from examining temporal relationships between variables. Furthermore, lower reliability of scales of coping strategies has certainly underestimated its relationships to PTSD symptoms, thus enhancing Type II error. In further studies, it could be more productive to combine the self-reporting method with structured interviews, medical records and additional measures, such as quality of life. Research on larger and more representative samples of war veterans is needed to explore the generalizability of these results. Certainly, the effectiveness of psychosocial treatment of dysphoria (by replacing escape-avoidance with positive reappraisal coping strategy) on the mental health status of war veterans would provide the best test of ecological validity of our findings.

Despite its limitations, this study represents a step toward better practical and methodological understanding of the relationship between PTSD symptoms and coping strategies. Earlier studies have shown that the type and time of traumatic experience, as well as the time period between the exposure to trauma and inclusion in the study, can influence assessment of PTSD and its consequences (Armour, 2015; Bensimon et al., 2013). The strength of the present study is in the selection of a very homogeneous veteran population, regarding all the above-mentioned criteria. Also, previous studies on this subject usually explored only the total score of PTSD symptoms. We investigated which dimensions of four-factor PTSD model are related to coping strategies, thus extending previous research and providing suggestions for therapeutic interventions about which specific coping strategies are inversely related to PTSD levels in this population. Our study suggests that the focal interest of a psychosocial treatment aimed at promoting wellbeing of the war veterans with prolonged experience of dysphoria symptoms should be (a) diminishing the level of escape-avoidance, and (b) enhancing the positive appraisal coping strategies. By control- 
ling many factors and controlling for intercorrelation between both coping strategies and PTSD symptoms, our data examined their relationship in a more detailed manner.

\section{CONCLUSION}

Given that Croatian war veterans in this study reported on PTSD symptoms that they experience 20 years after the initial war trauma, the strong relation found between dysphoria and engagement and disengagement coping strategies may explain the chronicity of the PTSD symptoms. Understanding coping patterns associated with long-term PTSD persistence and progression may help to identify coping strategies by which even extreme trauma can be used for lifelong growth, and to guide development of effective interventions in countries that do not have a strategy in place for an effective mental health-care service for soldiers returning from the combat-zone. More research is needed to determine how these variables interact and how to best protect against lifelong negative consequences of combat exposure.

\section{REFERENCES}

Abouzeid, M., Kelsall, H. L., Forbes, A. B., Sim, M. R., \& Creamer, M. C. (2012). Posttraumatic stress disorder and hypertension in Australian veterans of the 1991 Gulf War. Journal of Psychosomatic Research, 72(1), 33-38. doi:10.1016/j.jpsychores.2011.08.002

Agaibi, C. E., \& Wilson, J. P. (2005). Trauma, PTSD, and resilience: A review of the literature. Trauma Violence Abuse, 6(3), 195-216. doi:10. $1177 / 1524838005277438$

Aldwin, C. M., Levenson, M. R., \& Spiro, A. (1994). Vulnerability and resilience to combat exposure: Can stress have lifelong effects? Psychology and Aging, 9(1), 34-44. doi:10.1037/0882-7974.9.1.34

Amir, M., Kaplan, Z., Efroni, R., Levine, Y., Benjamin, J., \& Kotler, M. (1997). Coping styles in post-traumatic stress disorder (PTSD) patients. Personality and Individual Differences, 23(3), 399-405. doi:10. 1016/S0191-8869(97)80005-0

Armour, C. (2015). The underlying dimensionality of PTSD in the diagnostic and statistical manual of mental disorders: Where are we going? European Journal of Psychotraumatology, 6. doi:10.3402/ejpt.v6. 28074

Bae, S. M., Hyun, M. H., \& Ra, Y. S. (2015). Mediating effects of forgiveness and emotion-focused coping on post-traumatic stress disorder symptoms caused by physical injury and perceived threat. Asia-Pacific Psychiatry, 7(2), 164-172. doi:10.1111/appy.12142

Benotsch, E. G., Brailey, K., Vasterling, J. J., Uddo, M., Constans, J. I., \& Sutker, P. B. (2000). War Zone stress, personal and environmental resources, and PTSD symptoms in Gulf War veterans: A longitudinal perspective. Journal of Abnormal Psychology, 109(2), 205-213. doi:10. 1037/0021-843X.109.2.205 
DRUŠ. ISTRAŽ. ZAGREB GOD. 25 (2016), BR. 3, STR. 353-370

KNEŽEVIĆ, M., KRUPIĆ D., ŠUĆUROVIĆ, S.: COPING STRATEGIES..
Bensimon, M. (2012). Elaboration on the association between trauma, PTSD and posttraumatic growth: The role of trait resilience. Personality and Individual Differences, 52(7), 782-787. doi:10.1016/ j.paid.2012.01.011

Bensimon, M., Levine, S. Z., Zerach, G., Stein, E., Svetlicky, V., \& Solomon, Z. (2013). Elaboration on posttraumatic stress disorder diagnostic criteria: A factor analytic study of PTSD exposure to war or terror. Israel Journal of Psychiatry and Related Sciences, 50(2), 84-90.

Bentler, P. M. (1990). Comparative fit indexes in structural models. Psychological Bulletin, 107(2), 238-246. doi:10.1037/0033-2909.107.2.238

Bentler, P. M. (2006). EQS 6 structural equations program manual. Encino, CA: Multivariate Software, Inc.

Blanchard, E. B., Jones-Alexander, J., Buckley, T. C., \& Forneris, C. A. (1996). Psychometric properties of the PTSD checklist (PCL). Behaviour Research and Therapy, 34(8), 669-673. doi:10.1016/0005-7967 (96)00033-2

Bliese, P. D., Wright, K. M., Adler, A. B., Cabrera, O., Castro, C. A., \& Hoge, C. W. (2008). Validating the Primary Care Posttraumatic Stress Disorder Screen and the Posttraumatic Stress Disorder Checklist with soldiers returning from combat. Journal of Consulting and Clinical Psychology, 76(2), 272-281. doi:10.1037/0022-006X.76.2.272

Brewin, C. R., \& Holmes, E. A. (2003). Psychological theories of posttraumatic stress disorder. Clinical Psychology Review, 23(3), 339-376. doi:10.1016/S0272-7358(03)00033-3

Brousse, G., Arnaud, B., Roger, J. D., Geneste, J., Bourguet, D., Zaplana, F., Blanc, O., Schmidt, J., \& Jehel, L. (2011). Management of traumatic events: Influence of emotion-centered coping strategies on the occurrence of dissociation and post-traumatic stress disorder. Journal of Neuropsychiatric Disease and Treatment, 7(1), 127-133. doi:10. 2147/NDT.S17130

Carvalho, T., Pinto-Gouveia, J., Cunha, M., \& da Motta, C. (2014). Development of exposure to combat severity scale of the combat experiences questionnaire (CEQ). Journal of Anxiety Disorders, 28(8), 938-946. doi:10.1016/j.janxdis.2014.09.024

Clark, L. A., \& Watson, D. (1995). Constructing validity: Basic issues in objective scale development. Psychological Assessment, 7(3), 309-319. doi:10.1037//1040-3590.7.3.309

Claycomb, M. A., Wang, L., Sharp, C., Ractliffe, K. C., \& Elhai, J. D. (2015). Assessing relations between PTSD's dysphoria and reexperiencing factors and dimensions of rumination. Plos One, 10(3). doi:10. 1371/journal.pone.0118435

Cohen, J., Cohen, P., West, S. G., \& Aiken, L. S. (2003). Applied multiple regression/correlation analysis in the behavioral sciences. Thousand Oaks, CA: Sage.

Ehlers, A., \& Clark, D. M. (2000). A cognitive model of posttraumatic stress disorder. Behaviour Research and Therapy, 38(4), 319-345. doi:10. 1016/S0005-7967(99)00123-0

Foa, E. B. (2011). Prolonged exposure therapy: Past, present, and future. Depression and Anxiety, 28(12), 1043-1047. doi:10.1002/da.20907 
DRUŠ. ISTRAŽ. ZAGREB GOD. 25 (2016), BR. 3 STR. 353-370

KNEŽEVIĆ, M., KRUPIĆ, D., SUCUUROVIĆ, S COPING STRATEGIES..
Folkman, S. (1984). Personal control and stress and coping processes: A theoretical analysis. Journal of Personality and Social Psychology, 46(4), 839-852. doi:10.1037/0022-3514.46.4.839

Folkman, S., \& Lazarus, R. S. (2011). Ways of coping questionnaire (WOC). Jastrebarsko: Naklada Slap Ltd.

Forbes, D., Creamer, M., \& Biddle, D. (2001). The validity of the PTSD checklist as a measure of symptomatic change in combat-related PTSD. Behaviour Research and Therapy, 39(8), 977-986. doi:10.1016/ S0005-7967(00)00084-X

Gutner, C. A., Rizvi, S. L., Monson, C. M., \& Resick, P. A. (2006). Changes in coping strategies, relationship to the perpetrator, and posttraumatic distress in female crime victims. Journal of Traumatic Stress, 19(6), 813-823. doi:10.1002/jts.20158

Hassija, C. M., Jakupcak, M., \& Gray, M. J. (2012). Numbing and dysphoria symptoms of posttraumatic stress disorder among Iraq and Afghanistan war veterans: A review of findings and implications for treatment. Behavior Modification, 36(6), 834-856. doi:10.1177/014544 5512453735

Hoge, C. W., Riviere, L. A., Wilk, J. E., Herrell, R. K., \& Weathers, F. W. (2014). The prevalence of post-traumatic stress disorder (PTSD) in US combat soldiers: A head-to-head comparison of DSM-5 versus DSM-IV-TR symptom criteria with the PTSD checklist. The Lancet Psychiatry, 1(4), 269-277. doi:10.1016/S2215-0366(14)70235-4

Hoge, C. W., \& Warner, C. H. (2014). Estimating PTSD prevalence in US veterans: Considering combat exposure, PTSD checklist cutpoints, and DSM-5. The Journal of Clinical Psychiatry, 75(12), E1439E1441. doi:10.4088/JCP.14com09616

Hu, L. T., \& Bentler, P. M. (1999). Cutoff criteria for fit indexes in covariance structure analysis: Conventional criteria versus new alternatives. Structural Equation Modeling: A Multidisciplinary Journal, 6(1), 1-55. doi:10.1080/10705519909540118

Johnsen, B. H., Eid, J., Laberg, J. C., \& Thayer, J. F. (2002). The effect of sensitization and coping style on post-traumatic stress symptoms and quality of life: Two longitudinal studies. Scandinavian Journal of Psychology, 43(2), 181-188. doi:10.1111/1467-9450.00285

Kaysen, D., Dillworth, T. M., Simpson, T., Waldrop, A., Larimer, M. E., \& Resick, P. A. (2007). Domestic violence and alcohol use: Trauma-related symptoms and motives for drinking. Addictive Behaviors, 32(6), 1272-1283. doi:10.1016/j.addbeh.2006.09.007

Keane, T. M., Fairbank, J. A., Caddell, J. M., Zimering, R. T., Taylor, K. L., \& Mora, C. A. (1989). Clinical evaluation of a measure to assess combat exposure. Psychological Assessment, 1(1), 53-55. doi:10.1037/ 1040-3590.1.1.53

Lazarus, R. S. (1993). Coping theory and research: Past, present, and future. Psychosomatic Medicine, 55(3), 234-247. doi:10.1097/00006842199305000-00002

Lazarus, R. S., \& Folkman, S. (1984). Stress, appraisal, and coping. New York, NY: Springer.

Marshall, G. N., Schell, T. L., \& Miles, J. N. V. (2010). All PTSD symptoms are highly associated with general distress: Ramifications for 
DRUŠ. ISTRAŽ. ZAGREB GOD. 25 (2016), BR. 3, STR. 353-370

KNEŽEVIĆ, M., KRUPIĆ, D., ŠUĆUROVIĆ, S.: COPING STRATEGIES.. the dysphoria symptom cluster. Journal of Abnormal Psychology, 119(1), 126-135. doi:10.1037/a0018477

Monson, C. M., Schnurr, P. P., Resick, P. A., Freidman, M. J., Young$-\mathrm{Xu}, \mathrm{Y}$., \& Stevens, S. P. (2006). Cognitive processing therapy for veterans with military-related posttraumatic stress disorder. Journal of Consulting and Clinical Psychology, 74(5), 898-907. doi:10.1037/0022006X.74.5.898

Morris, M. C., \& Rao, U. (2013). Psychobiology of PTSD in the acute aftermath of trauma: Integrating research on coping, HPA function and sympathetic nervous system activity. Asian Journal of Psychiatry, 6(1), 3-21. doi:10.1016/j.ajp.2012.07.012

Mott, J. M., Mondragon, S., Hundt, N. E., Beason-Smith, M., Grady, R. H., \& Teng, E. J. (2014). Characteristics of U.S. veterans who begin and complete prolonged exposure and cognitive processing therapy. Journal of Traumatic Stress, 27(3), 265-273. doi:10.1002/jts.21927

Netemeyer, R. G., Bearden, W. O., \& Sharma, S. (2003). Scaling procedures: Issues and applications. Thousand Oaks, CA: Sage Publications. doi:10.4135/9781412985772

Palmieri, P. A., Weathers, F. W., Difede, J., \& King, D. W. (2007). Confirmatory factor analysis of the PTSD checklist and the clinician-administered PTSD scale in disaster workers exposed to the World Trade Center Ground Zero. Journal of Abnormal Psychology, 116(2), 329-341. doi:10.1037/0021-843X.116.2.329

Peterson, A. L., Luethcke, C. A., Borah, E. V., Borah, A. M., \& Young-McCaughan, S. (2011). Assessment and treatment of combat-related PTSD in returning war veterans. Journal of Clinical Psychology in Medical Settings, 18(2), 164-175. doi:10.1007/s10880-011-9238-3

Pietrzak, R. H., Goldstein, M. B., Malley, J. C., Rivers, A. J., \& Southwick, S. M. (2010). Structure of posttraumatic stress disorder symptoms and psychosocial functioning in Veterans of Operations Enduring Freedom and Iraqi Freedom. Psychiatry Research, 178(2), 323-329. doi:10.1016/j.psychres.2010.04.039

Pietrzak, R. H., Harpaz-Rotem, I., \& Southwick, S. M. (2011). Cognitive-behavioral coping strategies associated with combat-related PTSD in treatment-seeking OEF-OIF Veterans. Psychiatry Research, 189(2), 251-258. doi:10.1016/j.psychres.2011.07.019

Resick, P. A., Monson, C. M., \& Chard, K. M. (2014). Cognitive processing therapy: Veteran/military version: Therapist's manual. Washington, DC: Department of Veterans Affairs.

Sareen, J., Cox, B. J., Afifi, T. O., Stein, M. B., Belik, S. L., Meadows, G., \& Asmundson, G. J. (2007). Combat and peacekeeping operations in relation to prevalence of mental disorders and perceived need for mental health care. Findings from a large representative sample of military personnel. Archives of General Psychiatry, 64(7), 843-852. doi:10. 1001/archpsyc.64.7.843

Satorra, A., \& Bentler, P. M. (2001). A scaled difference chi-square test statistic for moment structure analysis. Psychometrika, 66(4), 507-514. doi:10.1007/BF02296192

Sharkansky, E. J., King, D. W., King, L. A., Wolfe, J., Erickson, D. J., \& Stokes, L. R. (2000). Coping with Gulf War combat stress: Mediating 
DRUŠ. ISTRAŽ. ZAGREB GOD. 25 (2016), BR. 3 STR. $353-370$

KNEŽEVIĆ, M., KRUPIĆ, D., SUCUROVIC, S. COPING STRATEGIES.. and moderating effects. Journal of Abnormal Psychology, 109(2), 188-197. doi:10.1037//0021-843X.109.2.188

Solomon, Z., Mikulincer, M., \& Flum, H. (1988). Negative life events, coping responses, and combat-related psychopathology: A prospective study. Journal of Abnormal Psychology, 97(3), 302-307. doi:10.1037/ 0021-843X.97.3.302

Steiger, J. H. (2000). Point estimation, hypothesis testing, and interval estimation using the RMSEA: Some comments and a reply to Hayduk and Glaser. Structural Equation Modeling: A Multidisciplinary Journal, 7(2), 149-162. doi:10.1207/S15328007SEM0702_1

Tiet, Q. Q., Rosen, C., Cavella, S., Moos, R. H., Finney, J. W., \& Yesavage, J. (2006). Coping, symptoms, and functioning outcomes of patients with posttraumatic stress disorder. Journal of Traumatic Stress, 19(6), 799-811. doi:10.1002/jts.20185

Wilkins, K. C., Lang, A. J., \& Norman, S. B. (2011). Synthesis of the psychometric properties of the PTSD checklist (PCL) military, civilian, and specific versions. Depression and Anxiety, 28(7), 596-606. doi:10.1002/da.20837

Wisco, B. E., Marx, B. P., Wolf, E. J., Miller, M. W., Southwick, S. M., \& Pietrzak, R. H. (2014). Posttraumatic stress disorder in the US veteran population: Results from the National Health and Resilience in Veterans Study. The Journal of Clinical Psychiatry, 75(12), 1338-1346. doi:10.4088/JCP.14m09328

Zeiss, R. A., \& Dickman, H. R. (1989). PTSD 40 years later: Incidence and person-situation correlates in former POWs. Journal of Clinical Psychology, 45(1), 80-87. doi:10.1002/1097-4679(198901)45:1<80::AIDJCLP2270450112>3.0.CO;2-V

Zerach, G., Solomon, Z., Cohen, A., \& Ein-Dor, T. (2013). PTSD, resilience and posttraumatic growth among ex-prisoners of war and combat veterans. Israel Journal of Psychiatry and Related Sciences, 50(2), 91-99.

\section{Strategije suočavanja sa stresom kod ratnih veterana 20 godina nakon Domovinskog rata}

\author{
Martina KNEŽEVIĆ \\ Hrvatski studiii, Zagreb \\ Dino KRUPIĆ \\ Filozofski fakultet, Osijek \\ Sandra ŠUĆUROVIĆ
}

Zbor udruga veterana hrvatskih gardijskih postrojbi, Zagreb

Nakon povratka s bojišta mnogi vojnici nailaze na poteškoće prilikom prelaska iz vojnoga života u civilni. Izloženost životno opasnim situacijama, poput ratne traume, može prouzročiti i dugoročne posljedice. Istraživanja su pokazala 
DRUŠ. ISTRAŽ. ZAGREB GOD. 25 (2016), BR. 3, STR. $353-370$

KNEŽEVIĆ, M., KRUPIĆ D., ŠUĆUROVIĆ, S.: COPING STRATEGIES. simptoma posttraumatskoga stresnog poremećaja (PTSP). Cilj ovog istraživanja bio je ispitati kako se ratni veterani, koji su bili izloženi ratnim traumama prije 20 godina, trenutačno nose sa svakodnevnim stresom te kako su njihove strategije suočavanja sa stresom povezane s

četverofaktorskim modelom PTSP-a. U istraživanju je sudjelovalo 220 veterana Domovinskog rata između 38 i 75 godina. Ispitanici su ispunjavali Ljestvicu izloženosti borbi, Ljestvicu simptoma traume i Upitnik o načinima suočavanja sa stresom. Rezultati su pokazali pozitivnu korelaciju između disforije i strategije bijega/izbjegavanja suočavanja sa stresom te negativnu korelaciju između disforije i pozitivne ponovne procjene. S obzirom na to da su simptomi disforije povezani s kroničnim PTSP-om te slabijim odgovorom na terapijske intervencije, naši rezultati naglašavaju važnost liječenja simptoma disforije i promicanje aktivnih strategija suočavanja sa stresom.

Ključne riječi: stres, četverofaktorski model PTSP-a, strategije suočavanja sa stresom, ratni veterani, terapijske intervencije 